\title{
Assessment of the Impacts of Refinery Effluent on the Physico-chemical Properties of Ubeji Creek, Delta State, Nigeria
}

\author{
Odesiri-Eruteyan Eunice*, Obukohwo Frank, Uhribo Voke and Asibor Godwin \\ Environmental and Public Health Microbiology at the University of Benin, Benin City, Edo State, Nigeria
}

\begin{abstract}
Ubeji Creek in Delta State, Nigeria is an important source of surface water for residents in Warri area is continually being polluted by the regular introduction of wastes and effluents from industries. The impact of industrial effluent on the physico-chemical properties of Ubeji creek in Warri, Delta State was investigated to determine the quality of the water body as well as the extent of pollution. The data that were used in this study were generated from direct field measurements and laboratory analyses. Results of measured parameters showed variation in $\mathrm{pH}(7.04-7.22)$, total hardness (32.75-127.63 mg/l), turbidity (26.18-69.75 NTU), THC (2.61-9.37 mg/l), TDS (78.20-615.30 mg/l), TSS (12.63-13.34 mg/l), COD (12.85-49.10 mg/l), BOD (7.34-15.62 mg/l), EC (158.06-1270.80 $\mu \mathrm{s} / \mathrm{cm}), \mathrm{DO}(3.12-4.37 \mathrm{mg} / \mathrm{l})$, phosphate $(<0.01 \mathrm{mg} / \mathrm{l})$, bicarbonate $(1.23-17.85 \mathrm{mg} / \mathrm{l})$, sulphate $(6.52-37.44 \mathrm{mg} / \mathrm{l})$ and nitrate concentrations ranging from 0.28-39.01 mg/l. The results were compared with the DPR and FEPA permissible limits as well as the WHO allowable limits for potable water. The major sources of pollution were observed to be effluents from the industries and dump sites within and around the creek catchment. This is indicative of the ineffective treatment systems and illegal waste disposal practices. These effluents were observed to have negative impact on the creek's ecosystem and pose a health risk to several rural communities which rely on the receiving water body as their source of domestic water. In order to improve the ecological status of the creek, waste management practice of effluent treatment and strict enforcement of existing legislation to ensuring compliance.
\end{abstract}

Keywords: Ubeji creek; Effluent; Pollution; Sewage; Water quality

\section{Introduction}

Water bodies play an important role as they serve the purpose of water supply for domestic, industrial, agricultural and power generation. They are also utilized as a medium for the disposal of sewage and industrial waste. Most of streams and creeks have been unmindfully used for the disposal of domestic and industrial effluents far beyond their assimilative capacities [1]. Despite its importance, water is the most poorly managed resource in the world. The quality of water get vastly deteriorated due to unsustainable practices such as illegal waste disposal; improper water management and carelessness towards the environment and this has led to the scarcity of potable water affecting human health [2]. In all cases where man utilizes any of the provisions of nature, pollution is bound to happen. When this pollution continues without any form of control or mitigation, environmental degradation sets in. Unfortunately, industrialization is considered the cornerstone of development strategies due to its significant contribution to the economic growth and human welfare. The increasing rate of industrialization has also led to increased rate of industrial waste discharge on the receiving water bodies. Wastewater discharge from sewage and industries are major component of water pollution, contributing to oxygen demand and nutrient loading of the water bodies, promoting toxic algal blooms and leading to a destabilized aquatic ecosystem [3]. The initial effect of effluents is to alter the natural physical and chemical status of the receiving water body. Biological degradation and microbial growth gradually becomes evident in terms of number, variety and organization of the living organisms in the water. Often the water bodies readily assimilate waste materials they receive without significant deterioration of some quality criteria; the extent of this is referred to as its assimilative capacity $[4,5]$. Due to the non-compliance of sustainable regulatory measures and incompetence of purification systems, waste water may become dangerous, leading to the accumulation of toxic products in the receiving water bodies with potentially serious consequences on the ecosystem. Presence of pollutants in natural waters alters the quality and often poses serious threats to aquatic life. Various studies have shown positive correlation between pollutions from petrochemical and refinery effluents and the health of aquatic organisms [6].

Niger delta ecosystem has been subjected to destruction by petroleum product spillage and other effluents resulting from operational activities [7]. The contents of the effluents have serious toxicological effects on aquatic environment and humans. When industrial effluent is discharged into a water body, it can cause depletion of dissolved oxygen due to transformation of organic component into inorganic compounds, loss of biodiversity through a decrease in amphipod population that is important in food chain, eutrophication and short term toxicity in fishes [8]. Recent study of Ubeji creek revealed that fish and aquatic life were absent at the site of effluent discharge and at each site downstream to Ubeji River [9]. Ubeji creek has been unmindfully used for the disposal of domestic waste and industrial effluents [1]. The unlawful and unregulated disposal of wastes and effluents have negative impact on the creek's ecosystem and pose a health risk to several rural communities which rely on the receiving water bodies as their source of domestic water. Residents relying on the creek's water resource for domestic purposes are exposed to hazard as they may be ignorant on the current quality status of the creek. The main objective of this study is therefore to determine the physiochemical properties of Ubeji creek and discharged effluent; impact of the effluent on the receiving

*Corresponding author: Odesiri-Eruteyan Eunice, Environmental and Public Health Microbiology at the University of Benin, Benin City, Edo State, Nigeria, Tel: +2347098805057; E-mail: odesiri.e.eunice@gmail.com

Received November 07, 2016; Accepted December 22, 2016; Published January 09, 2017

Citation: Eunice OE, Frank O, Voke U, Godwin A (2017) Assessment of the Impacts of Refinery Effluent on the Physico-chemical Properties of Ubeji Creek, Delta State, Nigeria. J Environ Anal Toxicol 7: 428. doi: 10.4172/2161-0525.1000428

Copyright: () 2017 Eunice OE, et al. This is an open-access article distributed under the terms of the Creative Commons Attribution License, which permits unrestricted use, distribution, and reproduction in any medium, provided the original author and source are credited. 
Citation: Eunice OE, Frank O, Voke U, Godwin A (2017) Assessment of the Impacts of Refinery Effluent on the Physico-chemical Properties of Ubeji Creek, Delta State, Nigeria. J Environ Anal Toxicol 7: 428. doi: 10.4172/2161-0525.1000428

Page 2 of 6

creek and suggest workable solutions to address any observed negative impacts on the environment.

\section{Materials and Methods}

The study area includes Ubeji creek, Warri Refinery and Petrochemical Company (WRPC) and surrounding communities in Delta State Nigeria. The refinery is bounded by three communities; Ekpan, Jeddo and Ubeji. It is located between latitude $5^{\circ} 25^{\prime} \mathrm{N}$ and $5^{\circ} 40^{\prime} \mathrm{N}$ and longitude $5^{\circ} 30^{\prime} \mathrm{E}$ and $5^{\circ} 47^{\prime} \mathrm{E}$. Industrial wastes and effluents are discharged into Ubeji creek through some minor creeklets. The Creek flows through Crawford Creek into Warri river which eventually empties into the Atlantic Ocean through the Bight of Benin (Figure 1).

\section{Sample collection}

Water and effluent samples were collected from three (3) sampling points 120 meters upstream and downstream respectively from the point of discharge along the creek's water course as well as from the point of discharge using $2 \mathrm{~L}$ plastic sampling bottles by dipping the bottles few centimetres below the water level. Samples for biological oxygen demand (BOD) were collected using BOD sampling bottle and incubated. Samples for oil and grease analysis were collected with glass bottle and preserved using $2 \mathrm{ml}$ 1:1 $\mathrm{H} 2 \mathrm{SO} 4$ acid. Collected samples were preserved in an ice chest and moved to the laboratory for analysis.

\section{Physicochemical analyses}

Analyses of certain physical parameters such as colour, odour and taste were carried out using physical examination. Standard methods were adopted for the various in-situ and laboratory analyses of water and effluent samples according to APHA (2009). Temperature, pH, total dissolved solids (TDS), dissolved oxygen (DO), electrical conductivity (EC) and turbidity were analysed in-situ to ensure the results clearly reflect the natural condition of the samples.

\section{Statistical analyses}

The data collected were analyzed using descriptive statistics such as mean and standard deviation.

\section{Results}

Detailed result of various physicochemical parameters of Ubeji creek is given in Table 1 . The results are expressed in mean \pm standard error.

The physical and chemical parameters investigated have been widely used to assess the impact of effluents on the water quality of African lakes, ponds, reservoir, freshwater and marine waters [10]. The various parameters assessed are presented in Figures 2-6.

\section{Discussion}

Colour, odour and taste are a measure of the physical characteristics of drinking water. Potable water is expected to be colourless, odourless and tasteless, but samples collected from the creek were found to be light brown in colour, with objectionable odour and taste. The colour

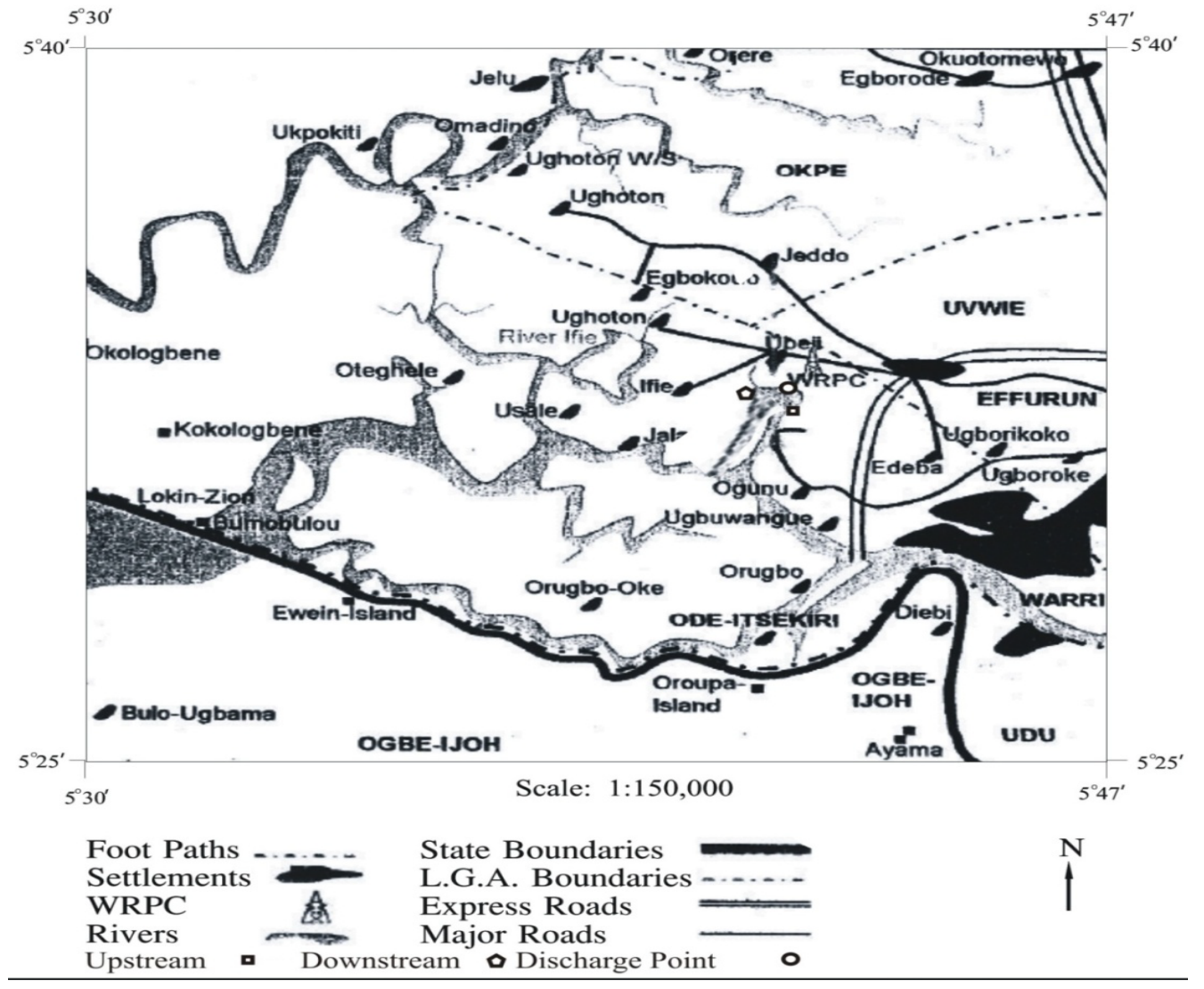

Figure 1: Map of the study area showing sample locations. 
Citation: Eunice OE, Frank O, Voke U, Godwin A (2017) Assessment of the Impacts of Refinery Effluent on the Physico-chemical Properties of Ubeji Creek, Delta State, Nigeria. J Environ Anal Toxicol 7: 428. doi: 10.4172/2161-0525.1000428

Page 3 of 6

\begin{tabular}{|c|c|c|c|c|c|c|}
\hline Parameter & Upstream & Discharge Point (Effluent) & Downstream & DPR Limit (Effluent) & FEPA Limit (Effluent) & WHO Limit (Portable Water) \\
\hline Colour & Light Brown & Light Brown & Light Brown & $\mathrm{N} / \mathrm{A}$ & $\mathrm{N} / \mathrm{A}$ & Colourless \\
\hline Odour & Unobjectionable & Unobjectionable & Unobjectionable & $\mathrm{N} / \mathrm{A}$ & $\mathrm{N} / \mathrm{A}$ & Odourless \\
\hline Taste & Objectionable & Objectionable & Objectionable & N/A & N/A & Tasteless \\
\hline $\mathrm{pH}$ & $7.2 \pm 0.1$ & $6.8 \pm 0.05$ & $7.0 \pm 0.05$ & $6.5-8.5$ & $6-9$ & $6.5-8.5$ \\
\hline Temp. $\left({ }^{\circ} \mathrm{C}\right)$ & $23.86 \pm 0.08$ & $24.91 \pm 0.04$ & $24.32 \pm 0.02$ & 30.0 & $<40$ & $24-30$ \\
\hline $\mathrm{THC}(\mathrm{mg} / \mathrm{l})$ & $2.61 \pm 0.32$ & $9.37 \pm 0.21$ & $2.68 \pm 0.23$ & 20.0 & 20.0 & $\mathrm{~N} / \mathrm{A}$ \\
\hline Turbidity (NTU) & $26.18 \pm 0.05$ & $69.75 \pm 0.1$ & $26.23 \pm 0.05$ & $\mathrm{~N} / \mathrm{A}$ & N/A & 4.0 \\
\hline TDS (mg/l) & $78.20 \pm 0.24$ & $615.30 \pm 0.15$ & $81.40 \pm 0.20$ & 5000 & 2000 & 500 \\
\hline TSS (mg/l) & $13.34 \pm 0.13$ & $12.63 \pm 0.14$ & $13.03 \pm 0.16$ & $\mathrm{~N} / \mathrm{A}$ & $<10.0$ & N/A \\
\hline $\mathrm{COD}(\mathrm{mg} / \mathrm{l})$ & $12.85 \pm 0.30$ & $49.10 \pm 0.44$ & $14.78 \pm 0.21$ & 125 & 40.0 & 10 \\
\hline $\mathrm{BOD}(\mathrm{mg} / \mathrm{l})$ & $7.34 \pm 0.04$ & $15.62 \pm 0.02$ & $9.15 \pm 0.02$ & 125 & 10.0 & $<4.00$ \\
\hline $\mathrm{EC}(\mu \mathrm{s} / \mathrm{cm})$ & $158.06 \pm 0.11$ & $1270.80 \pm 0.09$ & $160.02 \pm 0.13$ & $\mathrm{~N} / \mathrm{A}$ & 2500.0 & 500.0 \\
\hline $\mathrm{DO}(\mathrm{mg} / \mathrm{l})$ & $4.37 \pm 0.02$ & $3.12 \pm 0.03$ & $3.48 \pm 0.01$ & N/A & $8-10$ & $8-10$ \\
\hline Total Hardness (mg/l) & $32.73 \pm 0.14$ & $127.63 \pm 0.06$ & $45.69 \pm 0.08$ & N/A & $\mathrm{N} / \mathrm{A}$ & 300 \\
\hline Phosphate (mg/l) & $<0.01$ & $<0.01$ & $<0.01$ & N/A & 5 & $<0.1$ \\
\hline Bicarbonates (mg/l) & $1.23 \pm 0.03$ & $17.85 \pm 0.02$ & $1.74 \pm 0.02$ & N/A & 50 & 45.0 \\
\hline Sulphates (mg/l) & $6.52 \pm 0.03$ & $37.44 \pm 0.02$ & $7.34 \pm 0.02$ & N/A & 50 & 20.0 \\
\hline Nitrates (mg/l) & $0.28 \pm 0.00$ & $39.01 \pm 0.01$ & $1.35 \pm 0.01$ & $\mathrm{~N} / \mathrm{A}$ & 20 & 50.0 \\
\hline
\end{tabular}

N/A: Not Applicable; Source: FEPA (1991), DPR (1987) and WHO (1999)

Table 1: Showing results of various physico-chemical parameters of samples, DPR, FEPA and WHO limits for potable water.

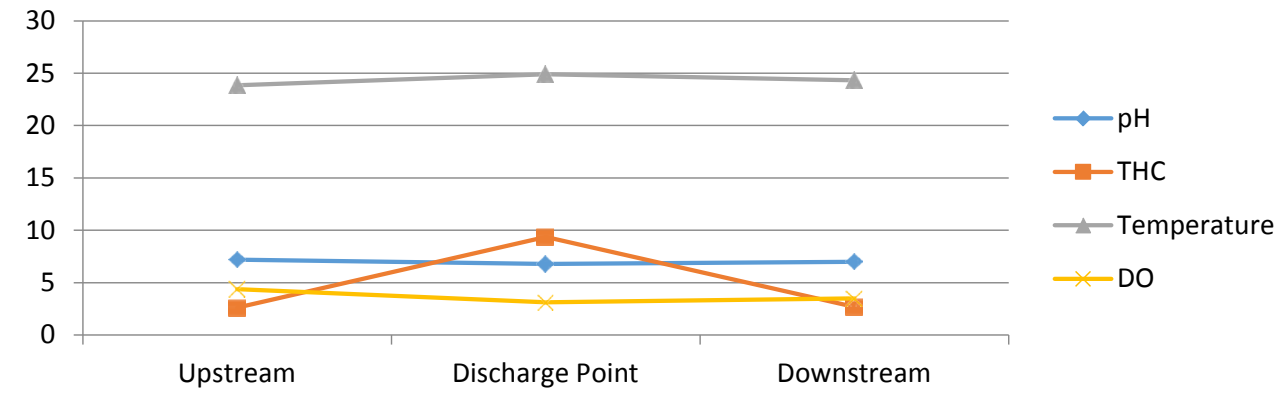

Figure 2: Variation in measured $\mathrm{pH}, \mathrm{THC}$, Temperature and DO.

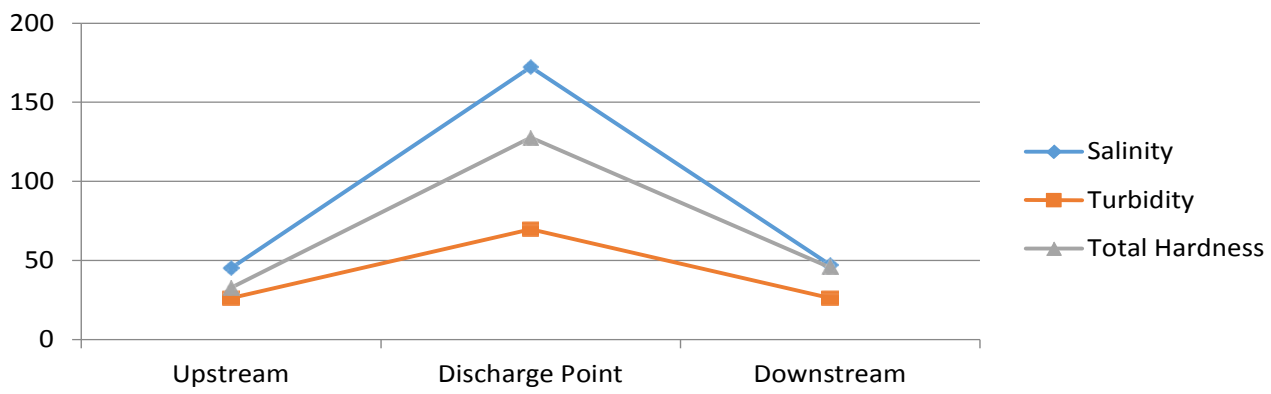

Figure 3: Variation in measured salinity, turbidity and total hardness.

of effluent may be as a result various industrial processes. This could be as a result of high dissolved salts content or anthropogenic activities upstream. Unusual odours or tastes which indicate a problem may be as a result of biological degradation occurring in a water body especially in a lentic water systems. From the table, water samples from the study area of the creek were analyzed to have turbidity values ranging from 26.18 NTU to 26.23 NTU. Turbidity is the measure of relative clarity of a liquid. It is an optical characteristic of water and is an expression of the amount of light that is scattered by material in the water when a light is shined through the water sample. This is due to fine particles suspended in the water, causing cloudiness. The higher the intensity of scattered light the higher the turbidity and material responsible for making water to be turbid include soil runoffs. The slight variation of turbidity values may be as a result of natural dilutions down the water course as the effluent (with turbidity value $69.75 \mathrm{NTU}$ ) was introduced midstream. The turbidity values of the water samples from the upstream and the downstream sections of the creek did not comply with WHO standard. The high turbidity value of the effluent is due to 
Citation: Eunice OE, Frank O, Voke U, Godwin A (2017) Assessment of the Impacts of Refinery Effluent on the Physico-chemical Properties of Ubeji Creek, Delta State, Nigeria. J Environ Anal Toxicol 7: 428. doi: 10.4172/2161-0525.1000428

Page 4 of 6

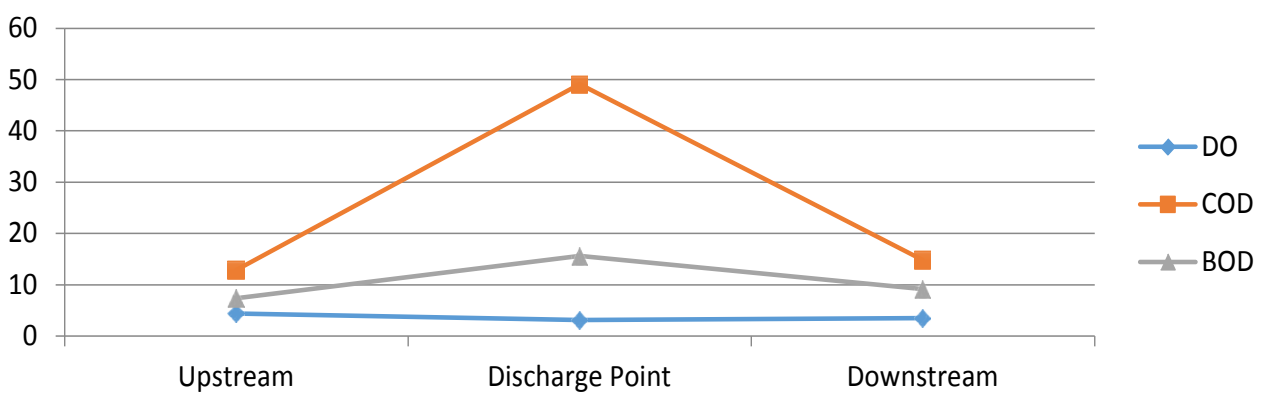

Figure 4: Variation in measured DO, COD and BOD.

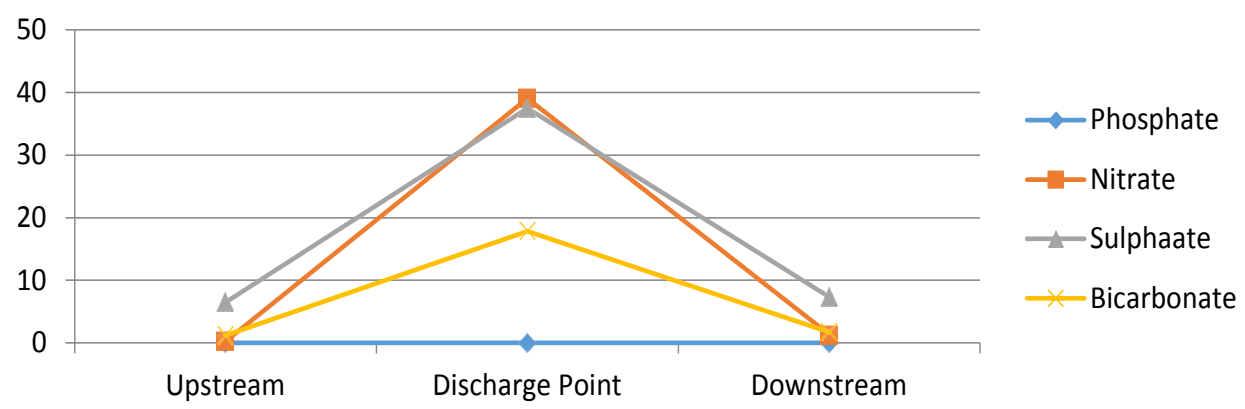

Figure 5: Variation in the measured concentration of phosphate, nitrate, sulphate and bicarbonate.

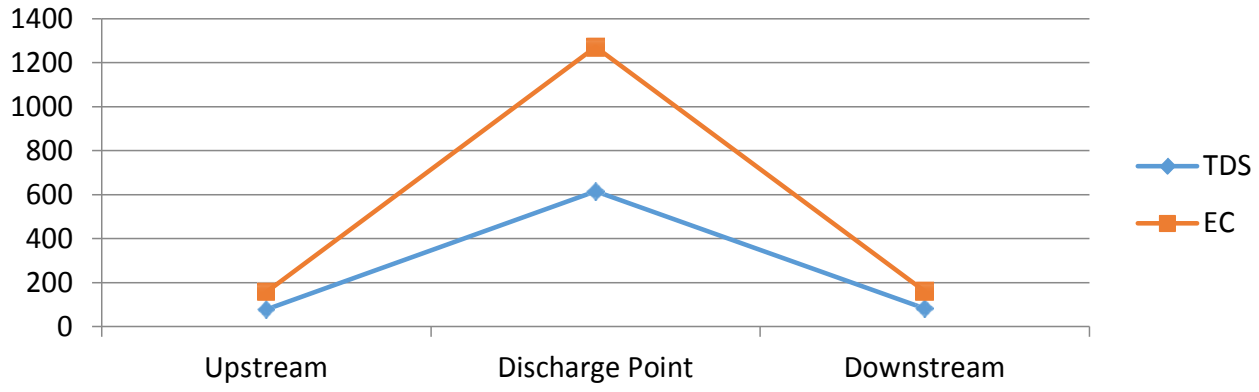

Figure 6: Variation in measured TDS and EC.

high amounts of suspended and colloidal matter such as clay, silt, finely divided organic and inorganic matter accumulated during industrial processes and from runoffs.

The amount of total suspended solids of the effluent sample (12.63 $\mathrm{mg} / \mathrm{l}$ ) showed to have a lower value relative to the water samples from both the upstream and downstream sections $(13.34 \mathrm{mg} / \mathrm{l}$ and $13.03 \mathrm{mg} / \mathrm{l}$ respectively) of the study area. The water and effluent samples failed to comply with FEPA allowable limit of $10.0 \mathrm{mg} / \mathrm{l}$. The relatively higher TSS values in water samples from both sections of the water course suggests that wastes are being added to the water from other sources apart from the industrial effluents. This may be as a result of rainstorm deposition or runoffs from the creek's surrounding. The temperature and $\mathrm{pH}$ of the effluent as well as that of the upstream and downstream sections of the water course were within DPR and FEPA limits [11].

TDS measured at the discharge point was $615.30 \mathrm{mg} / \mathrm{l}$ and was within both DPR and FEPA limits but above the WHO potable water limit of $500 \mathrm{mg} / \mathrm{l}$. The values at the upstream and downstream $(78.20$ $\mathrm{mg} / \mathrm{l}$ and $81.40 \mathrm{mg} / \mathrm{l}$ respectively) satisfy WHO potable water limit showing a corresponding increase of about $4.09 \%$. The high. TDS in water can cause changes in taste, excessive scaling in water pipes, water heaters, boilers and household appliances.

Dissolved oxygen (DO) is the amount of oxygen in a water or effluent sample. Moderate DO levels in surface water body indicate the ability to support aquatic life. Organic wastes utilize DO for biological decomposition and inorganic compounds also utilize oxygen in reduced state for oxidation. DO level was found to have dropped from 4.37 $\mathrm{mg} / \mathrm{l}$ in the upstream section to $3.48 \mathrm{mg} / \mathrm{l}$ in the downstream section of the creek. This may be as a result of the continuous introduction of effluents midstream, reduction in the rate of atmospheric oxygen absorption or reduced rate of photosynthesis in the downstream segment of the creek. The decreased DO level at the downstream section of the creek may also be due to the turbulence in the river water and increased competition for oxygen within the ecosystem. The high organic and inorganic pollutants received by water bodies through the discharge of industrial, sewage and solid wastes, require a high oxygen 
Citation: Eunice OE, Frank O, Voke U, Godwin A (2017) Assessment of the Impacts of Refinery Effluent on the Physico-chemical Properties of Ubeji Creek, Delta State, Nigeria. J Environ Anal Toxicol 7: 428. doi: 10.4172/2161-0525.1000428

Page 5 of 6

demand resulting in oxygen depletion. The DO level of the effluent was analyzed to be $3.12 \mathrm{mg} / \mathrm{l}$. The DO level of the effluent satisfied FEPA's allowable limit while the water samples from both sections of the creek was analyzed to be potable as DO levels were below WHO limit.

BOD values of water samples from the upstream and downstream sections of the creek varied from $7.34 \mathrm{mg} / \mathrm{l}$ to $9.15 \mathrm{mg} / \mathrm{l}$ while the treated effluent had a BOD value of $15.62 \mathrm{mg} / \mathrm{l}$. The increase of BOD value between the upstream and the downstream may be as a result of organic material contamination in water, accumulation of decomposable organic matter or high rate of sewage introduction beyond the assimilative capacity of the creek. Having satisfied the DPR limit of $125 \mathrm{mg} / \mathrm{l}$, the effluent's BOD value was found to be higher than FEPA's allowable limit of $10 \mathrm{mg} / \mathrm{l}$, hence, non-compliance. The BOD values of both sections of the water course do not satisfy the WHO limit of $<4.0 \mathrm{mg} / \mathrm{l}$, hence, renders it unsafe for consumption. Chemical Oxygen Demand (COD) is the amount of oxygen required for the oxidation of inorganic matter using a strong chemical oxidant. The higher the chemical oxygen demand, the higher the amount of pollution in the test sample. COD levels for the upstream and downstream sections of the creek were analyzed to be $12.85 \mathrm{mg} / \mathrm{l}$ and $14.78 \mathrm{mg} / \mathrm{l}$ respectively while that of the effluent was found to be $49.10 \mathrm{mg} / \mathrm{l}$. From the table, the effluent's COD level showed to be below DPR limit of $125.0 \mathrm{mg} / \mathrm{l}$ but above FEPA limit of $40.0 \mathrm{mg} / \mathrm{l}$. The higher level of COD in the effluent discharged indicate that it contains high oxygen demanding materials, which causes depletion of dissolved oxygen in water thereby limiting its use for other purposes such as irrigation and recreational purposes. The high BOD and COD levels in water samples indicated that the water was highly polluted. It may be attributed to the high demand on dissolved oxygen by the wastes discharged into the water bodies. The upstream and downstream water samples exhibited higher levels of COD with respect to WHO limit for potable water thereby making the water from the creek unfit and unsafe for drinking.

The low chloride levels in both sections of the creek may be due to natural dilutions from excessive rainfall. Elevated chloride levels may be as a result of water additives used to control microbes and disinfect water. Elevated levels in water can cause eye/nose irritation; stomach discomfort, increase corrosive character of water. Sulphate content of water samples from both sections of the creek varied from $6.52 \mathrm{mg} / \mathrm{l}$ to $7.34 \mathrm{mg} / \mathrm{l}$. This complied with WHO sulphate content limit for potable water. The low sulphate values may also be from dilution and the high velocity of the water due to excessive rainfall. The effluent was analyzed to have a relatively high sulphate value $(37.44 \mathrm{mg} / \mathrm{l})$ compared to those of the water samples. This is due to relatively higher levels of dissolved $\mathrm{Ca} / \mathrm{Mg} / \mathrm{Fe}$ sulphates. Elevated sulphate contents may lead to gastro-intestinal irritation and calcium sulphate scale in pipes. This occurs naturally in many source waters after contact with particular mineral deposits and rock strata. The concentrations normally found in drinking water do not represent a risk to health.

Runoff from agricultural site or residential buildings deposits detergent into water body, since detergents are among the greatest contributors to phosphate content in streams. Phosphate-containing compounds are used in detergent formulation as water softeners. Phosphate is not toxic to animals or plants. In fact, it is a plant nutrient, which stimulates the growth of microbes, molds, aquatic weeds and algae. These phosphates become detrimental as they accumulate overtime leading to natural aging of a water body through a process known as eutrophication (algae bloom). The concentration of phosphate in water samples from both sections of the creek as well as that of the treated effluent were analyzed to be $<0.01 \mathrm{mg} / \mathrm{l}$. Phosphate levels in the water samples and effluent complied with WHO limit of $<0.1 \mathrm{mg} / \mathrm{l}$ and FEPA limit of $5.0 \mathrm{mg} / \mathrm{l}$ respectively. Possible sources could be from the release of phosphates from phosphorous detergents discharged along with the sewage waste.

Total hardness of water indicates the presence of calcium $(\mathrm{Ca} 2+$ and magnesium $(\mathrm{Mg} 2+)$ ions in a water supply. These ions exist to some degree in every water supply. WHO's maximum permissible level of hardness in potable water is $300 \mathrm{mg} / \mathrm{l}$. Total hardness of water samples varied from $32.73 \mathrm{mg} / \mathrm{l}$ to $45.69 \mathrm{mg} / \mathrm{l}$ while that of the effluent had an analytical value of $127.63 \mathrm{mg} / \mathrm{l}$. The water samples is said to be potable having complied with WHO maximum limit of $300 \mathrm{mg} / \mathrm{l}$. The relatively high value of the water sample from the downstream section of the creek may be attributed to the mixing of sewage or effluents with water flowing from the upstream section of the creek. Hardness causes poor lather formation with soap, deterioration of the quality of clothes, scale forming incrustations in distribution systems and excessive soap consumption.

Inorganic fertilizers from agricultural runoff are the main source of nitrate in water supplies but it can occur from natural sources such as leaking from septic tanks, sewage and erosion of natural deposits. A commonly used method of nitrate reduction is to blend with a low nitrate source; however it can be removed by treatment using an ion exchange process. High levels of nitrate may have effect on Infants below the age of six months with symptoms such as shortness of breath and blue-baby syndrome. Nitrate concentration of water samples from the upstream and downstream sections of the study area showed to be $0.28 \mathrm{mg} / \mathrm{l}$ and $1.35 \mathrm{mg} / \mathrm{l}$ respectively while that of the effluent was analyzed to have a $39.01 \mathrm{mg} / \mathrm{l}$. The water and effluent samples complied with the WHO and FEPA allowable limits respectively.

\section{Conclusion}

Relatively higher concentrations of most of the measured parameters from the water sample from the downstream of the creek are suggestive of input of effluents into the water from industries around the creek catchment. By virtue of the present water quality status of Ubeji creek in comparison with the World Health Organization guidelines for drinking water quality [12-15] threshold for drinkable water, the water within the study area cannot be said to be safe for human consumption or suitable for domestic use as some of the measured parameters such as the oxygen demanding levels which exceed the allowable limits. The water may be detrimental to the growth and development of aquatic lives due to high levels of some of the measured parameters. Also, measured parameters such as sulphate concentration, COD and BOD levels exceed FEPA's permissible limit for surface water [16]. High contents of oxygen demanding parameters often deplete the amounts of dissolved oxygen which is harmful to aquatic lives. The results reveal that the water quality status of Ubeji creek is adversely impaired with the discharge of industrial effluents as notable variations of measured parameters were observed between the upstream and the downstream sections of the creek's water course. This impairment within the study area is as a result of the continuous effluent discharge from the Warri Refinery and Petrochemical Company (WRPC) midstream of the study area. This has led to significant environmental and health risk to the rural communities who rely on the receiving water as their source of domestic water purpose without treatment.

\section{References}

1. Arimoro FO (2009) Impact of rubber effluent discharges on the water quality and macroinvertebrate community assemblages in a forest stream in the Niger Delta. Chemosphere 77: 440-449. 
Citation: Eunice OE, Frank O, Voke U, Godwin A (2017) Assessment of the Impacts of Refinery Effluent on the Physico-chemical Properties of Ubeji Creek, Delta State, Nigeria. J Environ Anal Toxicol 7: 428. doi: 10.4172/2161-0525.1000428

Page 6 of 6

2. Alina B (2015) Pollution Facts and Types of Pollution.

3. Morrison G, Fatoki OS, Persson L, Ekberg A (2001) Assessment of the impact of point source pollution from the Keiskammahoek Sewage Treatment Plant on the Keiskamma River - $\mathrm{pH}$, electrical conductivity, oxygen-demanding substance (COD) and nutrients. Water SA 27: 475-480.

4. Adekunle AS (2009) Effects of industrial effluent on quality of well water within Asa Dam Industrial Estate, Ilorin, Nigeria. Nature and Science 7: ISSN 1545-0740.

5. Adekunle AS, Eniola IT (2008) Impact of industrial effluents on quality of segment of Asa river within an industrial estate in Ilorin, Nigeria. New York Science Journal 1: 17-21.

6. Otukunefor TV, Obiukwu CO (2005) Impact of refinery influent on physicochemical properties of a water body on the Niger Delta. Appl Ecol Environ Res 3: 61-72.

7. Adeniyi AA, Afolabi JA (2002) Determination of total petroleum hydrocarbons and heavy metals in soils within the vicinity of facilities handling refined petroleum products in Lagos metropolis. Environment International 28: 79-82.

8. Beeby A (1993) Measuring the effect of Pollution. In: Applying Ecology. Chapman and Hall, London, New York.
9. Achudume AC (2009) The Effect of Petrochemical Effluent on the Water Quality of Ubeji.

10. Nhiwatiwa T, Marshall BE (2007) Water quality and plankton dynamics in two small dams in Zimbabwe. African Journal of Aquatic Science 32: 139-151.

11. DPR (1987) Guidelines and standards for environmental pollution control in Nigeria. Department of Petroleum Resources, Nigeria.

12. WHO (1984) Guidelines for Drinking-Water Quality. Health Criteria and other Supporting Information. World Health Organization, Geneva 2: 335.

13. WHO (1991) GEMS/WATER 1990-2000. The Challenge Ahead. WHO/ PEP/91.2, World Health Organization, Geneva.

14. WHO (1993) Guidelines for Drinking-Water Quality. Recommendations. 2nd edn. World Health Organization, Geneva 1: 188.

15. WHO (1999) Guidelines and standards for drinking water. World Health Organization.

16. FEPA (1991) Guidelines and standards for environmental pollution control in Nigeria. Federal Environmental Protection Agency, Lagos, Nigeria. 